Forcada N., Angela P. Alvarez., Love P.E.D., Edwards D. Rework in Urban Renewal Projects in Colombia. Journal of Infrastructure Systems, 2016, <doi: 10.1061/(ASCE)IS.1943-555X.0000332 >

Final version available at: < http://ascelibrary.org/doi/abs/10.1061/(ASCE)IS.1943-555X.0000332>.

\title{
Rework in Urban Renewal Projects in Colombia
}

\author{
Nuria Forcada ${ }^{1}$, Angela P. Alvarez ${ }^{2}$, Peter E.D. Love ${ }^{3}$, David J. Edwards ${ }^{4}$ \\ 1 Group of Construction Research and Innovation (GRIC), Universitat Politècnica de Catalunya, C/ \\ Colom, 11, Ed. TR5, 08222 Terrassa, Barcelona, Spain. E-mail: nuria.forcada@upc.edu (corresponding \\ author). \\ 2 Group of Construction Research and Innovation (GRIC), Universitat Politècnica de Catalunya, C/ \\ Colom, 11, Ed. TR5, 08222 Terrassa, Barcelona, Spain. E-mail: alvarezangelap@ gmail.com \\ 3 Department of Civil Engineering, Curtin University, GPO Box U1987, Perth, WA 6845, Australia. E- \\ mail: p.love@curtin.edu.au \\ 4 Birmingham School of the Built Environment, Birmingham City University, Birmingham, B4 7XG, \\ United Kingdom. E-mail: drdavidedwards@aol.com
}

\begin{abstract}
There a paucity of systematic knowledge on the dynamics of rework in urban renewal projects even though such projects frequently exceed budget and schedule. The causal factors of rework and cost impact upon 69 Colombian public projects are examined. The nomenclature of Project, Organization and People (POP) is used to categorize causal variables and develop a generic systemic model of rework causation. Inadequate initial budgets, poor project design (which instigated changes during construction) and the socially inclusivity of contracts in Colombia (which employ local inexperienced people to conduct the required works), were the most significant contributors of rework. The developed model provides decision-makers and stakeholders with insights about the interdependencies and behaviour between key influencing variables in Colombian urban renewal projects and can be used to stimulate learning and process improvements in future projects.
\end{abstract}

Author keywords:

Colombia, public urbanisation projects, rework, system dynamics. 


\section{INTRODUCTION}

The Colombian economy has been experiencing considerable economic growth; Foreign Direct Investment and exports have increased (OECD, 2015). In 1998, for example, the Colombian government engaged in a transformation plan to re-develop and maintain its inner cities via the Decree 1504 (1998) and the Manual of Design and Construction of Public Spaces (Alcaldia de Cali, 2003). From 2001 the city of Medellin, for example, has experienced a renaissance in urban renewal (e.g., neighbourhood improvements and heritage conservation), which has been supported by several Municipal Development Plans (MDP) (Alcaldia de Medellin, 2001; 2004; 2012) and the encouragement of active citizen participation. The Medellin municipality consequently developed a local planning program entitled the 'Participatory Budgeting Program' (PBP) (Alcaldia de Medellin, 2010). The PBP provides motivation for active citizen participation in democratically organized local planning processes. The PBP also allocates public resources by prioritizing citizen's infrastructural demands and needs, thus integrating development and the cities' own local processes within their districts. Major defining characteristics of the PBP are (Alcaldia de Medellin, 2010):

- each district's representative submits the most important and urgent urban works (decided by the community) within the district to the municipality for review and budgetary assignment. This process normally takes one year from the proposal being submitted to works execution;

- before construction initiation, a community socialization meeting is carried out;

- the contractor must employ at least $80 \%$ of local (often, unskilled) people;

- while subcontracting is prohibited in Colombian public works sector, it is permitted when specialization works are required such as paving and installation of handrails; and

- when modifying a project's scope, the community's permission is required.

These major defining characteristics of the PBP (such as employing unskilled people) provoked high indexes of rework in most projects under this program.

Rework has been defined as the "unnecessary effort of re-doing an activity or process that was incomplete the first time" (Love 2002, p. 19). Rework often arises from design changes, errors and omissions that stem from scope uncertainty and the contracting strategy adopted (e.g., Burati et al., 1992; Love et al., 2011). The inherent degree of uncertainty that prevails within an urban renewal project's scope creates a problematic issue, especially when information is unavailable. Consequently, this affects decisionmakers' choices during a project's formative stages (Alessandri et al., 2004). In the absence of available knowledge, decisions made prior to, or during construction are erroneous and lead to disastrous consequences (Love et al., 2013). When uncertainty is high, initial drawings and specifications will invariably change, and the project team seek to resolve problems as they arise during construction. Once changes arise, they may be deemed to be ambiguous, erroneous and invariably require rework (Forcada $e t$ al., 2014).

Rework has, on average, been found to contribute to $52 \%$ of a project's total cost overrun and increase schedule overruns by as much as 22\% (Love, 2002). Moreover, rework have been found to range from $5 \%$ to $20 \%$ of a contract's value in construction 
and engineering projects with design scope changes rework accounting for as much as $50 \%$ of costs (e.g., Barber et al., 2000; Love and Edwards, 2004). Yet, limited knowledge exists about rework costs in urban renewal projects even though such costs negatively impact upon project performance and organizations' profitability (Rogge et al., 2001; Love, 2002; Dissanayake et al., 2003; Love and Edwards, 2004; Fayeket al., 2004; Palaneeswaran et al., 2008; Hwang et al., 2009; Zhang et al., 2012; Forcada et al., 2014). Essentially, urban renewal projects tend to focus on renovations, refurbishment, modernizations of transportation infrastructure (e.g., pavements, roads, stairways) and parks. There is a proclivity for such projects to be small and oriented to small facility maintenance and modification projects (Zhang et al., 2012) or rural transit projects with remote locations (Tran et al., 2015).

Against this contextual backdrop, the causal nature of rework that arose in 69 Colombian urban renewal projects under the PBP is examined. The findings are used to develop an influence diagram to determine the inter-relationships between variables that contributed to rework as well as time and cost variations that were experienced. The developed model provides decision-makers and stakeholders with an ameliorated understanding of rework dynamics and can be used as a tool to stimulate learning and process improvement. The paper commences with a description of the case study (including the data collection methods that were used) before presenting the nomenclature for rework causation. This nomenclature is then used to analyse the rework causation and develop the dynamics of rework in the provided case study. Results are then discussed and conclusions are drawn.

\section{RESEARCH APPROACH}

A case study should investigate the technical aspects of a contemporary phenomenon within a real life context, particularly in critical and unique circumstances (Yin, 1984). It is particularly useful when the boundaries between phenomenon and context are difficult to ascertain and when multiple sources of evidence are used (Yin, 1984). A case study provides analytical rather than pure statistical generalizations and can capture the complexity and dynamism of organizational settings in projects (Flyvbjerg 2006). For these reasons, this research adopts a case study approach to examine underlying dynamics that contribute to rework in urban renewal projects.

\subsection{CASE BACKGROUND}

Urban renewal projects in the city of Medellin (Colombia) within the PBP provide the paper's case study setting. These projects include the construction of sidewalks, curbs, stairways, supply and installation of road protections, handrails and complementary works in different parts of the district. A traditional lump sum contract was employed where the Secretaría de Obras Públicas acted as the contracting party for all projects. The initial contract value was 486.431.898 COL\$ (Colombian peso ( $1 €=2,500$ COL\$)) and the initial contract duration was 120 days; this included 49 projects within 17 districts. However, the contract grew to finally encompass 69 small independent subprojects within 21 geographical districts of the city. Hence, the revised contract value was increased to $717,310,539 \operatorname{COL} \$$ and the contract duration to 180 days. 
Despite being a single contract, each district was independent in terms of budget allocation and could not transfer funds to other districts. Similarly, there was neither a specific planning policy for the execution of works nor a sequence of order for the projects. However, there was a global milestone for the execution of the entire program of works but no independent milestones individual projects. Figure 1 presents areas of the city prior to the commencement of construction works.
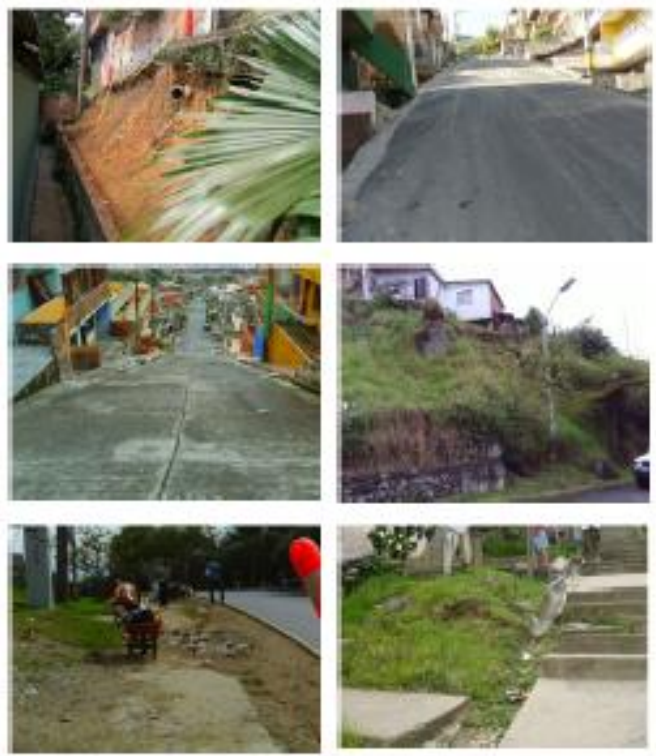

Figure 1. Examples of different areas of the city before carrying out the works

\subsection{DATA COLLECTION}

The research team acted as non-participant observers throughout the duration of on-site data collection, which commenced from the construction phase. The team also utilized their industrial experience to identify rework events that occurred while inspecting historical contract documentation such as site instructions, change order requests, requests for information and drawing changes. To categorise events as rework, validation was sought from the contractor's project manager, site foreman, and client's representative. Every attempt was made to avoid disrupting the workflow of the site management team and workers or bias their responses to questions posed. However, as the research relied on reports of individuals' historical events, some biases due to recall and self-preservation were inevitable.

Thus, independent verification of the ensuing discourse generated by interviewees was confirmed using multiple sources and triangulation to obtain a balanced view of events. Specifically, triangulation cross checked for internal consistency and reliability, and tested the data's external validity. Documentation provided by the administration (e.g. contract information and payment orders) and unstructured interviews with project team members (e.g. client's representative, contractor, site managers and subcontractors) represented primary sources of information for determining both the causes and costs of rework experienced. Once a rework event was identified, all respective parties involved 
with identification and rectification were interviewed to elicit a balanced view of the event. Interview data and narratives were then transcribed and given to the interviewee to check for any discrepancies that may have arisen.

\subsection{DATA ANALYSIS}

The interview narratives and textual content obtained from secondary documentation were then analysed using the QSR NVivo 9 software. This software has the inherent capability to organize and analyse unstructured qualitative information, words and concepts with powerful processes of indexing and theorising. This enabled the research team to quantify and analyse the presence, meanings and relationships of words and concepts, as well as draw inferences about the messages contained within the texts. It also enabled additional data sources such as web pages and journal notes to be incorporated into the analysis in the pursuit of identifying new emergent themes. QSR NVivo 9 facilitated an organic approach to coding by enabling triggers or categories of textural interest to be coded and used to monitor emerging and developing ideas (Kvale, 1996). This coding can be modified, integrated or migrated as the analysis progresses and facilitates the recognition of conflicts and contradictions (Morse and Richards 2002). Coding was undertaken systematically to ensure all data was treated equally. As an initial step, all interview transcripts were read in their entirety and notes made by members of the research team. These initial notes were used to formulate categories, connect themes, and help develop contextual relationships between themes.

The analysis commenced by examining themes associated with 'change', 'error', 'cost' and 'mistakes'. Using an in-built function within QSR NVivo 9, words with similar meanings such as mistake and error were identified in selected materials ('sources'). This functionality enabled the research team to manoeuvre from one data source to the next using features called 'doc links', 'node links' and 'data links'. The process adopted involved creating 'nodes' to mark relevant concepts and topics in text documents that were subsequently searched and analysed. The analysis revealed a high degree of interdependency existed between perceived rework sources. This resulted in the nomenclature of Project, Organization and People (POP) to be adopted akin to previous research conducted by Love et al., (2012) and Forcada et al., (2014), where the:

1. Project includes scope definition; wrong initial budget; lack or inadequate design; deterioration of the site regarding natural accidents; pressure to start work(s) execution; lack of clarity of citizen needs and specifications; type of procurement path; vandalism; climatic conditions and specifically inclement weather; and interferences with existing public services.

2. Organization includes lack of supervision; design changes; unexpected events; inadequate quality of execution; slow client resolution; inadequate budget management: third party problems: and inadequate resources management.

3. People includes lack of experience and expertise; and stress.

\section{REWORK CAUSATION}


The selected projects experienced significant cost variations due to changes, errors and omissions, which resulted in rework occurrence. Despite its presence, rework was not formally measured or acknowledged as there was a negative perception that 'admission' would damage the contractor's corporate reputation. However, the administration was curious to know 'why' and 'how' project rework arose. Through direct observation and subsequent analyse of interviews and documentation, the incidences and their causes, description, budget and cost modifications were detailed. Table 1 presents an example of the description of incidences that occurred.

\begin{tabular}{|c|c|c|c|c|c|}
\hline Rework incidence & Cause & Description & Responsible & $\begin{array}{c}\text { Time } \\
\text { increase }\end{array}$ & $\begin{array}{c}\text { Cost } \\
\text { increase }\end{array}$ \\
\hline $\begin{array}{l}\text { The client requested to continue the } \\
\text { platform until connecting it }\end{array}$ & & Extra work & & - & - \\
\hline $\begin{array}{l}\text { Pavement demolition was required } \\
\text { to give continuity to curbs. }\end{array}$ & $\begin{array}{l}\text { Scope } \\
\text { definition }\end{array}$ & Extra work & Client & 3 days & $41.15 \%$ \\
\hline $\begin{array}{l}\text { The big rock found in the excavation } \\
\text { was required to bring it to the } \\
\text { dumping site. }\end{array}$ & & $\begin{array}{l}\text { Addition } \\
\text { work }\end{array}$ & & 4 days & $2.49 \%$ \\
\hline $\begin{array}{l}\text { The design lacked of platform. It } \\
\text { had to be built. }\end{array}$ & $\begin{array}{l}\text { Wrong initial } \\
\text { budget }\end{array}$ & $\begin{array}{l}\text { Additional } \\
\text { work }\end{array}$ & Client & - & $9.60 \%$ \\
\hline $\begin{array}{l}\text { The exact location of the platform } \\
\text { had to be decided on site. }\end{array}$ & $\begin{array}{l}\text { Lack or } \\
\text { inadequate } \\
\text { design }\end{array}$ & $\begin{array}{l}\text { Only general } \\
\text { details were } \\
\text { received }\end{array}$ & Client & - & - \\
\hline \multirow{3}{*}{ Execution delays } & $\begin{array}{l}\text { Lack or } \\
\text { inadequate } \\
\text { design }\end{array}$ & $\begin{array}{l}\text { Lack of works } \\
\text { and procedure } \\
\text { definition. }\end{array}$ & $\begin{array}{l}\text { End users } \\
\text { (community) }\end{array}$ & 3 days & - \\
\hline & & Workers didn't & & & \\
\hline & $\begin{array}{l}\text { Lack of } \\
\text { experience }\end{array}$ & $\begin{array}{l}\text { know how to } \\
\text { carry out the } \\
\text { work. }\end{array}$ & Contractor & - & - \\
\hline $\begin{array}{l}\text { Site managers requested changing } \\
\text { the design. }\end{array}$ & Lack of clarity & $\begin{array}{l}\text { Lack of } \\
\text { communication } \\
\text { between parties }\end{array}$ & Client & 1 day & - \\
\hline \multirow{2}{*}{ Low efficiency } & $\begin{array}{l}\text { Type of } \\
\text { contract }\end{array}$ & $\begin{array}{l}\text { Workers didn't } \\
\text { know how to } \\
\text { carry out the } \\
\text { work. }\end{array}$ & Client & \multirow[b]{2}{*}{-} & \multirow[b]{2}{*}{-} \\
\hline & Stress & $\begin{array}{l}\text { Due to scope } \\
\text { changes, errors } \\
\text { and unexpected } \\
\text { events. }\end{array}$ & Contractor & & \\
\hline
\end{tabular}

Table 1. Example of the description of the incidences occurred in a project

From the analysis of rework incidences a taxonomy of causes based upon POP was developed and is presented in Table 2. The POP taxonomy enabled common factors contributing to rework to be identified prior to further examining each sub-project. The common significant factors influencing rework were identified as:

- Wrong initial budget: Poor documentation and technical designs/ specifications that were based solely upon the district representative's request (without on-site technical 
inspection and validation) brought many scope and budget modifications. For example, excavations with significant slope did not include a retaining wall. These extra works significantly increased construction costs and delayed the programme of works. Many of these rework events could be directly attributed to the: district representative's slow acceptance of changes; absence of technical site visits; and necessity of ordering new materials, and subsequent employment of specialized staff for the works. Other consequences of an inaccurate initial budget were: uncertainty and stress due to constant changes and new situations; a significant increase of work with the available resources; and overall confusion for the termination of works. This situation could have been avoided with the provision of accurate information design;

- Lack or inadequate design: Poor initial documentation created constant delays during construction works because of a lack of design clarity and supporting technical advice; the client's inability to reach resolution on design changes further exacerbated these problems. For example, project commencement was delayed by 10 days because the client had not approved key information;

- Scope definition: Scope changes were closely related to poor design documentation and erroneous initial budget calculations;

- Type of contract: The inherent degree of uncertainty within the scope of projects under PBP and in general of an urban improvement project created a problematic issue (Alessandri et al., 2004). The absence of detailed project design, inadequate allocation of budget and bureaucratic indecisions prior to, or during construction may lead to cost and schedule increases being experienced (Love et al., 2013). The obligation to seek permission via community socialization meetings before commencing (or changing) the works together with the requirement to hire $80 \%$ of unskilled labour from the district's citizens, were identified as contributory to rework;

- Inadequate economic solvency and inadequate budget management: The contractor's poor financial position was aggravated by inadequate budgetary management when allocating material and equipment resources amongst the various projects. In turn, resources shortages occurred, which result in rework and delays;

- Weather conditions: High temperatures and sporadic torrential rains caused the temporary suspension of some work - such incidents could only be classified under the heading of force majeure but better planning would be reduced the impact of inclement weather;

- Lack of experience: Workers' inexperience and incompetence resulted in substandard quality works such as: mixing incorrect proportions of grouting materials; failing to determining the correct thickness of concrete; and failing to ensure that surfaces were even, level and smooth (as per contractual specifications). Extreme pressure to complete works further exacerbated issues concerning the lack of works precision and led to repairs, scope changes, rework and delays;

- Unviable works: Unviable works appeared when a project or an activity could not be performed according to the contract content due to errors in the design documentation or a lack of resources allocated to that activity or project. Some designs were developed only with the request forms provided by the district's representative without ensuring the real location and situation of the site. Consequently, many errors appeared in the contract documentation. Several unviable projects were then redefined or replaced for other necessary works in the district. 


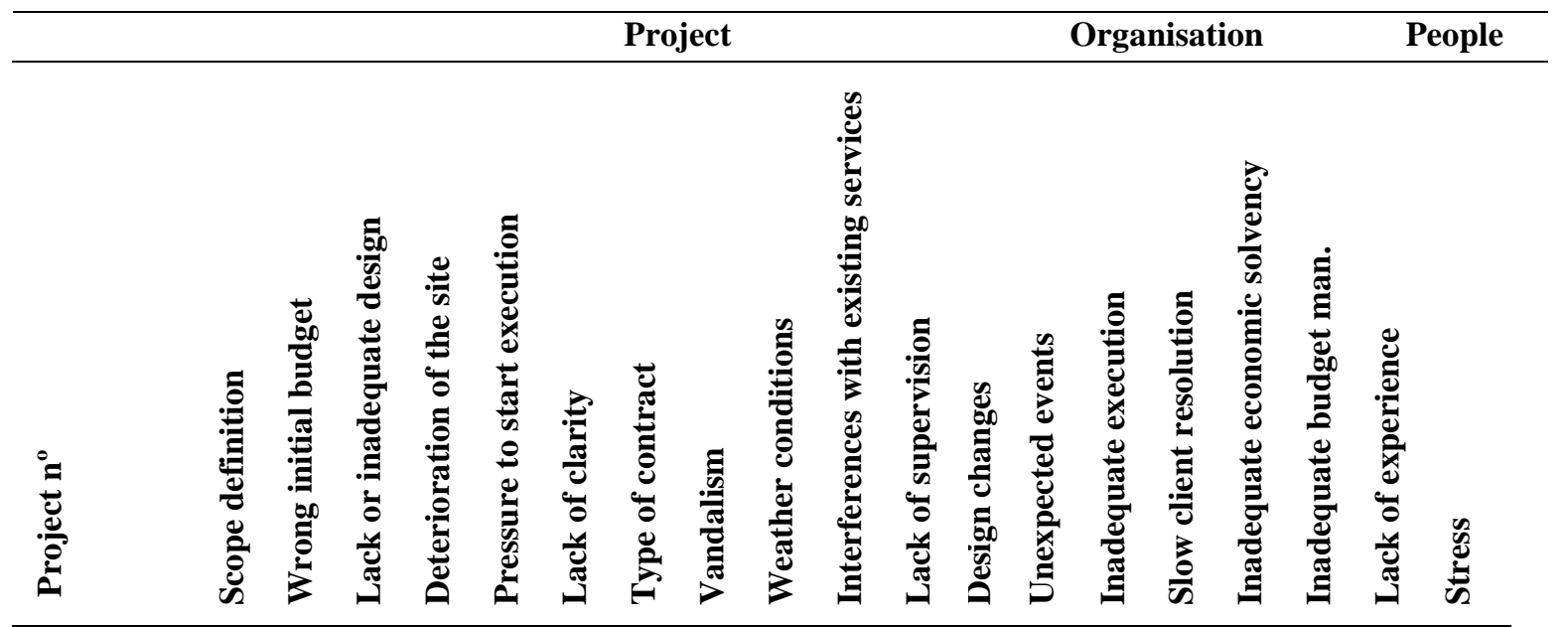

\section{District 1}

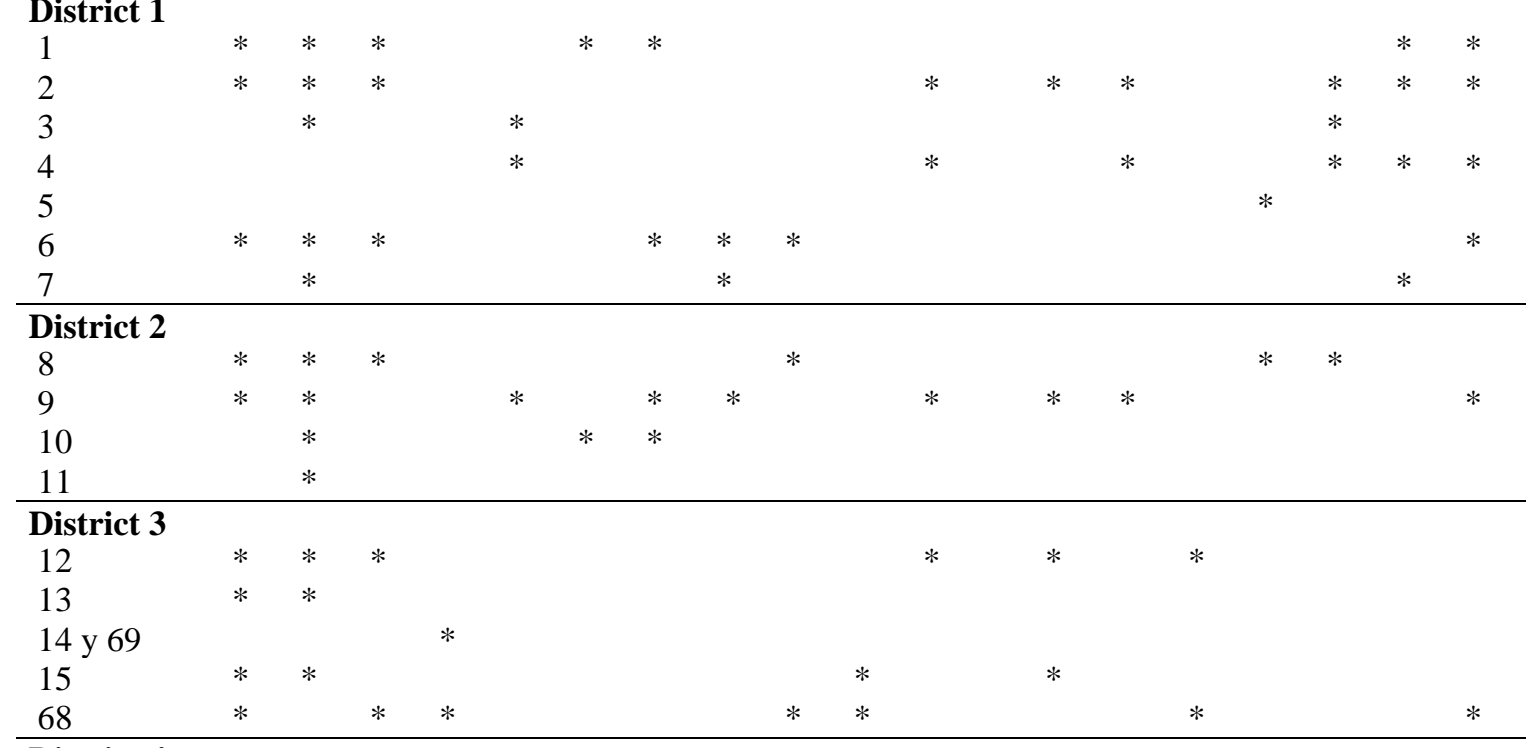

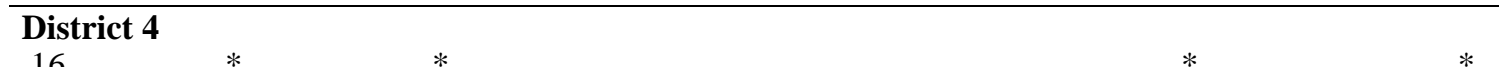

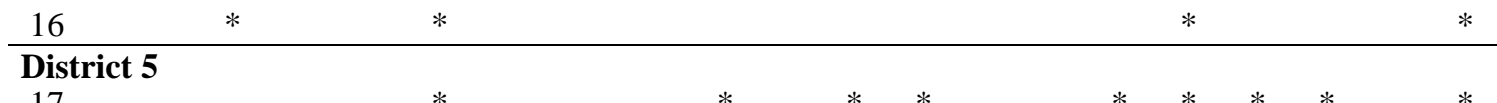

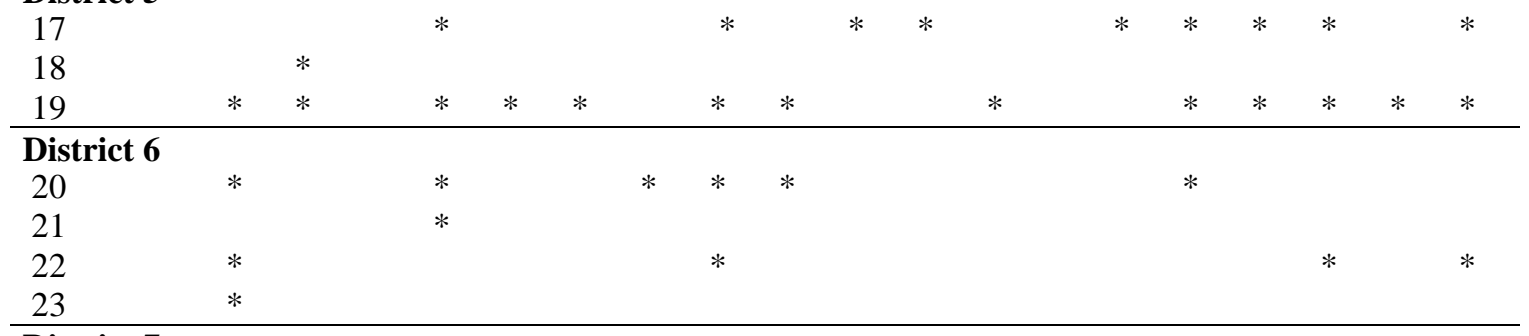

District 7

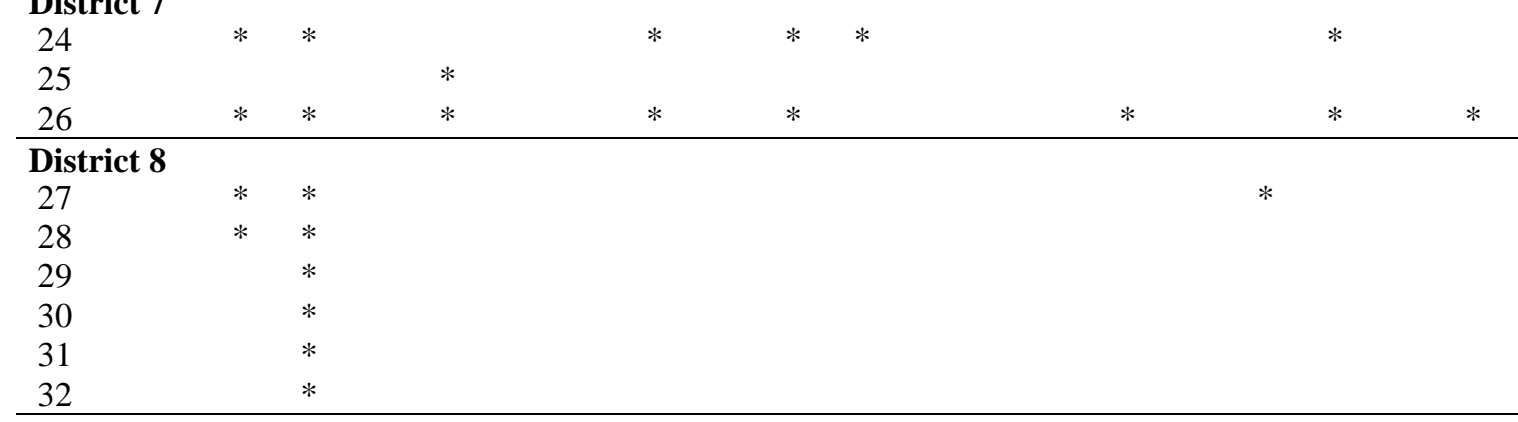

\section{District 9} 33

$* \quad *$

$*$

* $\quad *$

$*$

* 


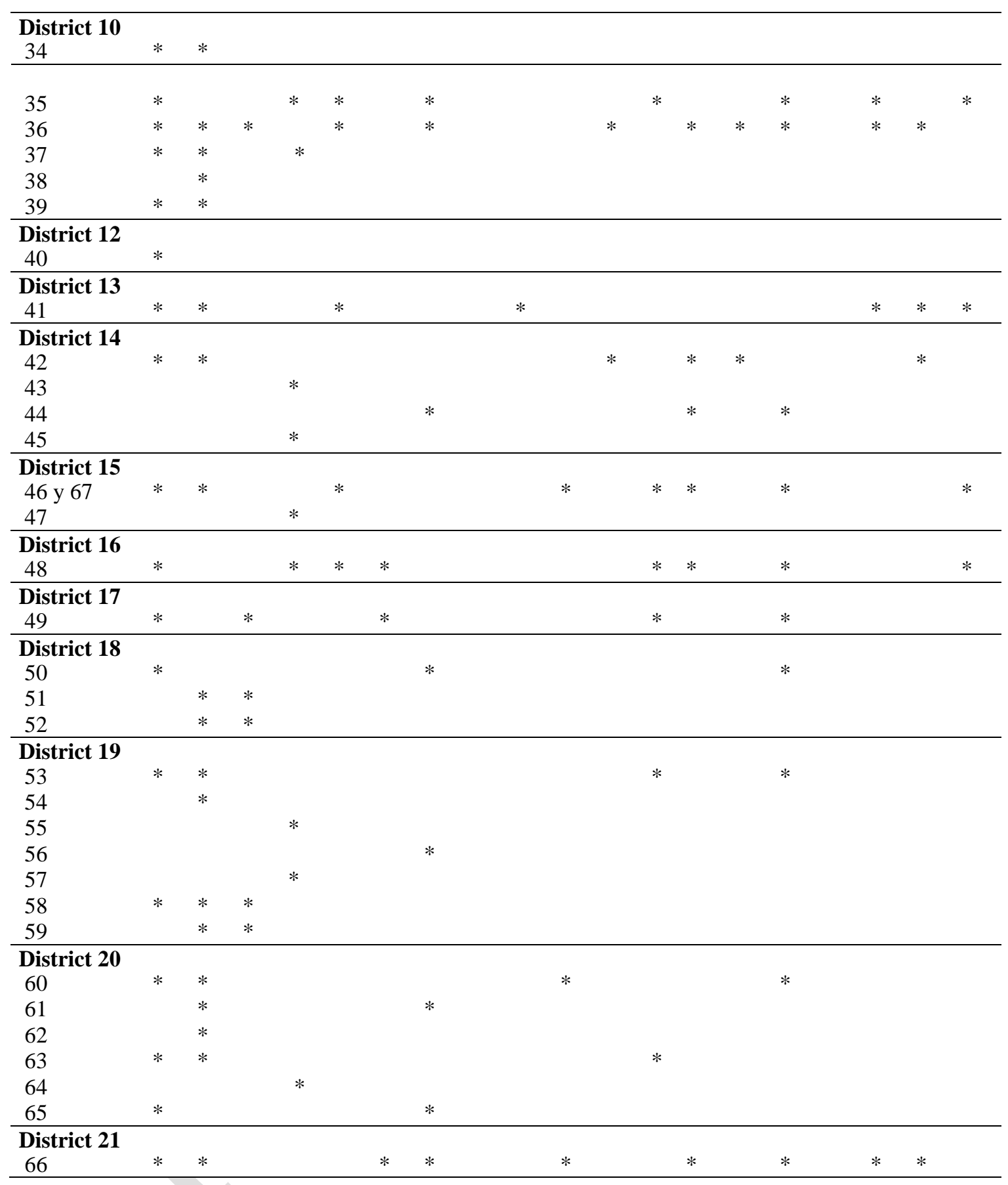

Table 2. Factors influencing rework in each project

It was identified that initial budgetary plans were a primary cause of rework; perhaps due to issues to optimism bias. A detailed analysis of such costs within each project was carried out. Table 3 presents a summary of analysis disaggregated by district and includes the: awarded budget; corrected budget (awarded budget modified and adapted to the work to be completed); rework costs due to unexpected events; rework costs due to scope modifications by the client; and final executed budget. 


\begin{tabular}{|c|c|c|c|c|c|c|c|c|c|c|}
\hline & 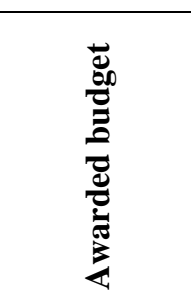 & 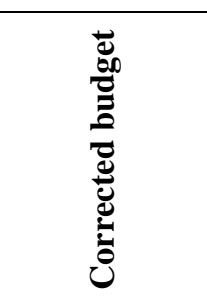 & 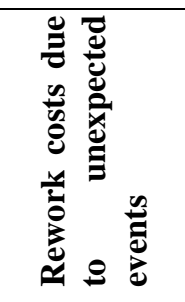 & 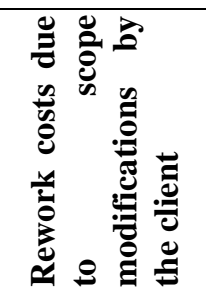 & 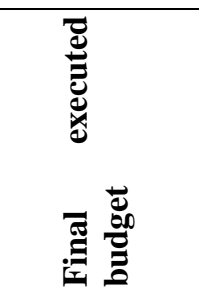 & 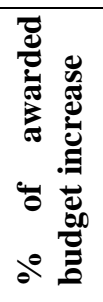 & 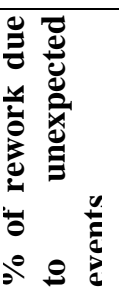 & 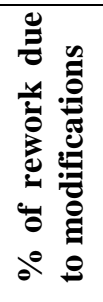 & 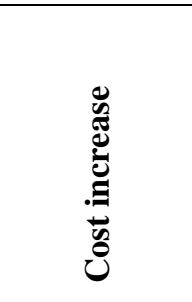 & 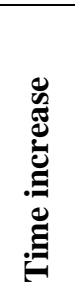 \\
\hline District 1 & $33,055,363$ & $30,098,080$ & 104,313 & $2,864,184$ & $33,066,576$ & 9.8 & 0.3 & 8.7 & 11,214 & 25 \\
\hline District 2 & 843,546 & $41,589,576$ & 274,950 & $99,787,916$ & $42,085,595$ & 0.6 & 0.7 & 237.1 & & 3 \\
\hline District 3 & $58,151,730$ & $26,414,940$ & 117,000 & $38,826,860$ & $60,042,426$ & 120.1 & 0.2 & 64.7 & & 14 \\
\hline District 4 & $16,764,998$ & $16,764,998$ & 0 & $10,256,630$ & 17,167 & 0.0 & 0.0 & 59.7 & & 42 \\
\hline Distri & 34,244 & 29,654 & 0 & $4,139,404$ & & 15.5 & 0.0 & 12.2 & & \\
\hline Distr & 3 & 38,146 & 0 & $55,490,710$ & & -7.4 & 0.0 & 173.7 & & 57 \\
\hline Distri & 3. & 22 & 0 & $16,105,560$ & & 45.6 & 0.0 & 48.8 & & 11 \\
\hline Distri & & 30,389 & 0 & $1,612,380$ & 200 & 0.7 & 0.0 & 5.0 & & 1 \\
\hline & & & 73,500 & 1,162 & & 11.0 & 0.5 & 7.9 & & 20 \\
\hline & & & 0 & $4,000,890$ & & 35.0 & 0.0 & 27.2 & & 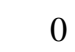 \\
\hline Distr & & 20,918 & 104,290 & $18,321,261$ & 34,005 & 67.3 & 0.3 & 53.9 & $-991,094$ & 41 \\
\hline Dist & 1 t & 17 & 0 & 0 & 17,134 & 0.0 & 0.0 & 0.0 & -450 & 0 \\
\hline Dis & & 1 & 0 & 0 & & 2.8 & 0.0 & 0.0 & -39 & 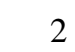 \\
\hline Dis & & 1 & $4,285,240$ & 712,616 & 32,0 & 87.5 & 44.6 & 2.2 & & 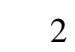 \\
\hline Dist & 75,3 & 37,2 & 0 & $51,164,610$ & $60,714,303$ & 102.1 & 0.0 & 84.3 & $-14,661,598$ & 36 \\
\hline Dist & 46,9 & $47,593,843$ & $2,078,633$ & $5,804,701$ & $50,520,528$ & -1.4 & 43.7 & 11.5 & & 13 \\
\hline Dist & & $29,503,283$ & 0 & $21,303,145$ & & -8.9 & 0.0 & 67.1 & $4,890,628$ & 15 \\
\hline Dis & & & & 15,210 , & & 18.0 & $0 .($ & 71.6 & -171 & 3 \\
\hline Dis & & & & 57,201 & & 34.1 & 0. & 87.4 & & 10 \\
\hline & & & 93,359 & 17,171, & 48 & 52.5 & 0. & 35.1 & & 10 \\
\hline District 21 & $22,472,234$ & $21,890,043$ & $1,572,025$ & $4,959,475$ & 25,52 & 2.7 & 6.2 & 19.4 & $3,056,684$ & 17 \\
\hline Total $\%$ & & 2 & & & & 28.0 & 4.6 & 51.3 & & \\
\hline Total (da & & & & 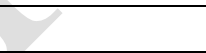 & & & & & & 322 \\
\hline Total COL\$ & 717,3 & $3,656,5$ & $38,703,309$ & $426,095,874$ & 110566 & & & & 75 & \\
\hline Total $€$ & 302,663 & 237,830 & 16,331 & 179,787 & 301,302 & & & & $-1,361$ & \\
\hline
\end{tabular}

Table 3. Analysis of the budget and costs of rework by district

Since many inconsistences between the design and what was actually documented were found (and with the aim to analyze the real costs of rework), the budget was recalculated to produce a corrected one accommodated actual work undertaken.

On average, the awarded budget was $28 \%$ above the corrected budget, illustrating that the budget was inflated. Had a detailed analysis of work activities been carried out during the design process, then this aforementioned inflation could have been avoided. It is estimated that tighter budgetary control and a detailed design at the outset of project inception could have saved 153,653,978 COL\$. Yet, the contract did not allocate any contingency for schedule nor cost overruns. In fact, the final executed budget was $3,224,875$ COL $\$$ less than the awarded budget mainly because one project was not carried out. Hence, when comparing the final executed budget to the awarded budget there is no cost increase. However, many budget modifications and budget exchanges were made between projects from the same district and sought not to overtake the 
awarded budget. By comparing the final executed budget with the corrected budget, a $21.1 \%$ increase in the corrected budget was recorded and was attributed to scope changes that transpired as cost and time overruns.

The contributors of rework can be categorized into various dichotomous groups such as client related, design related and contractor related factors (Love and Edwards 2004). Rework costs due to execution errors and management problems were incurred by the contractor, while rework costs due to scope modifications (client and design related factors) were incurred by the client but had to be allocated in the awarded budget. The wrong initial budget stemmed from an inaccurate design and provoked an awarded budget $28 \%$ above that forecasted; constant modifications and scope changes created by a lack of design clarity and the client's inability to reach timely resolution were the most important factor of cost increase. The average percent of rework costs due to design scope modifications by the client in each district, accounted for $51.3 \%$ of the project's total cost (including non-realized works). These results are in line with those previously reported upon by Barber et al. (2000) and Love and Edwards (2004). This cost increase was absorbed by other project modifications and by changing specifications. Rework costs due to unexpected events, accounted for $4.6 \%$ of the project's total cost. These costs were mainly due to the workers' lack of experience/ incompetence, pressure to finish works, stress and inadequate budget management when allocating material and equipment resources. These costs were absorbed by the contractor.

Table 3 illustrates that 322 days of schedule overrun were experienced and negatively affected the management of workmanship, materials and machinery by creating necessary changes and rework, and increasing cost. As some projects were carried out in parallel, any delays occurring in one district did not necessarily affect others. The development of projects in parallel helped deliver the contract in the 180 expected days. However, additional resources were commandeered and tasks were carried out concurrently. The reactionary scenario described is commonly referred to as Brookes Law (Cooper 1980). By pushing beyond the limits of acceptable levels of concurrency, complexity increases and destabilises the project (Cooper 1980). This further exacerbates the time to complete tasks, particularly when revisions, repairs and rework occur (Cooper 1980, Love 2002).

\section{DYNAMICS OF REWORK}

The analysis revealed that the causation of rework could not be attributed to a single factor - rather, a number of complex and interrelated factors were responsible. Consequently, a generic causal model was produced to demonstrate the existing interdependency between these factors (Table 2). This model took an account of these factors via direct observations, interviews with all the parties and documentary sources for the 69 projects. This information was subsequently integrated and implemented in a generic influence diagram (Figure 2). The arrows that link each variable indicate a place where a cause and effect relationship exists, while the plus or minus sign at the head of each arrow indicates the direction of causality between the variables. 


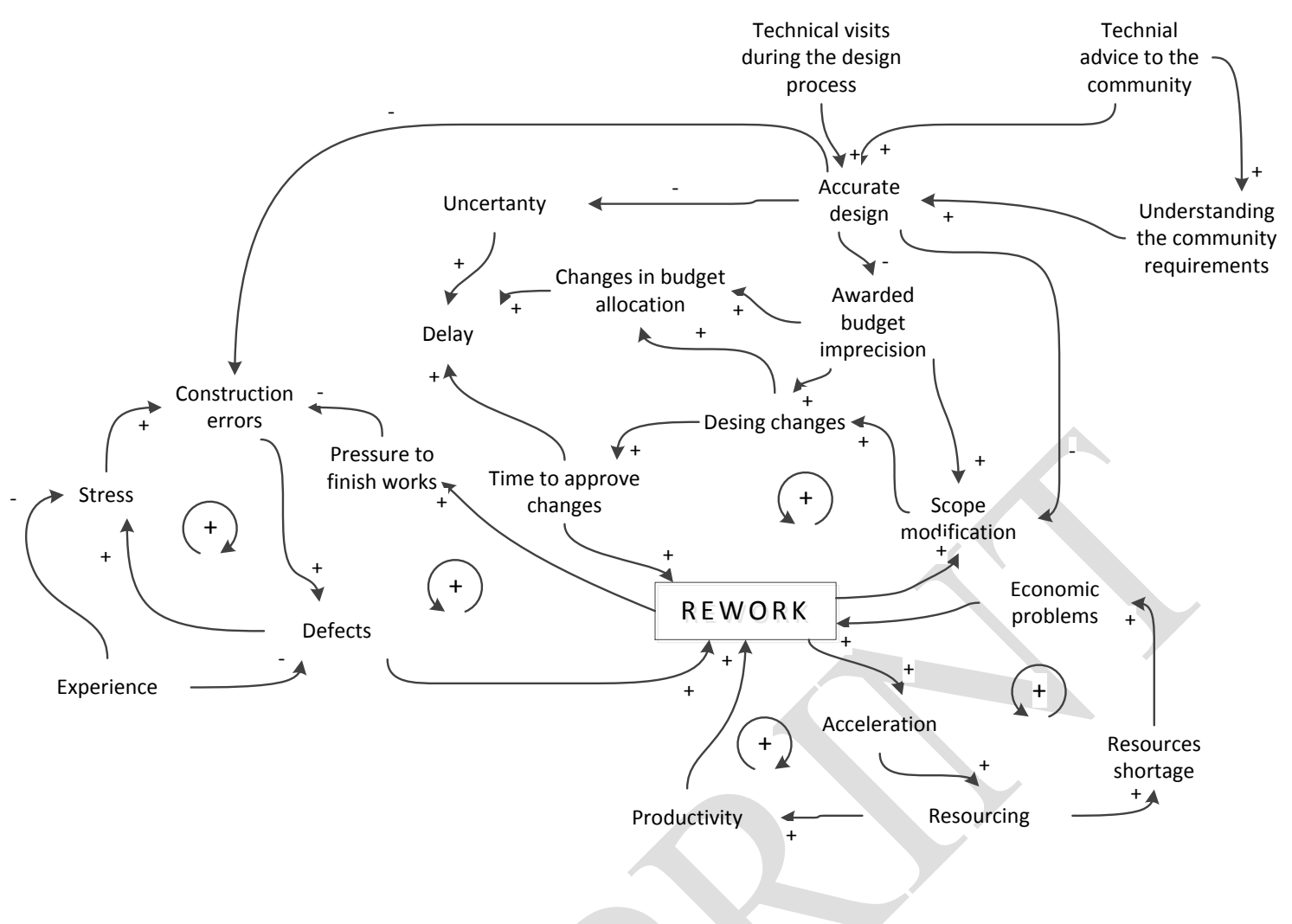

Figure 2.Generic influence diagram of rework

Unexpected situations such as inconsistencies between scope, budget and schedule, unanticipated problems or changes often initiate a series of dynamics that can provoke rework and thus, create substantial cost and schedule modifications (Forcada et al., 2014). For example, inadequate or incomplete designs and specifications increased the scope of works to be undertaken. In the case of Colombia urban renewal projects, the type of public contracts impact on rework and as a result, on the whole project's performance.

A lack of vernacular skills and knowledge within the community hindered scope development, increased workload and subsequently, subjected consultants to schedule pressure. Consequently, design errors and omissions arose within contract documentation. This was mainly because technical visits, reviews and verifications where not undertaken (Love et al., 2010a). Such errors and omissions were not identified until construction was being undertaken and therefore, a huge quantity of design modifications arose. Koskela and Huovila (1997) and Love et al. (1999) suggest that a design freeze should be applied as early as possible to minimise rework occurrence. A design freeze would have been effective only if highly skilled professionals developed the client's project brief to their requirements and effectively communicated this brief to all contractual participants involved. The time to rectify any error can affect the work's progress, require a costly design change and/ or lead to unscheduled programme overruns. Design errors identified during the construction phase are often the mostly costly to rectify (Burati et al., 1992; Love and Li 2000; Love et al., 2008). 
Inconsistences between actual construction work and specifications contained in the contract documentation were an important contributor to rework. In fact, scope uncertainty is an innate feature of Colombian urban renewal projects under the PBP. During this research, it emerged that the lack of technical visits by the municipality when defining the project's scope and end users' (community) inexperience in defining project needs also contributed to rework during construction (Palaneeswaran et al, 2008). The municipality allocated the budget to each project based on the community needs but a comprehensive design was not developed. The lack of technical visits when defining the project's scope and design generated many changes that had to be approved by the community; where the latter were slow to reach resolution thus creating further delays and rework. It was apparent that the community lacked construction knowledge and were bound by a protracted group decision-making process - in turn, this led to partial stops of work and schedule overruns. Furthermore, the extended period between drawing up the project and executing it caused deteriorations of several sites. Therefore, modifications in the scope were normal in all projects.

Colombian urban renewal projects have tended to be procured using the traditional lump sum methods (e.g., design-bid-construct). However, scope uncertainty and lack of contractor involvement during design provoked design changes and increased the initial awarded budget (Love et al., 2013). The wrong budget management coupled with the contractor's low financial capacity further exacerbated delays and cost increases. Contractor economic problems delayed the materials and equipment supply that led to imprecise execution procedures and further delays and cost increases as a result of rework. Similarly, productivity was affected by work quality, availability of prerequisites, out-of-sequence work, schedule pressure, morale, skill and experience, organizational size changes and overtime (Lyneis and Cooper 2001). The need to employ $80 \%$ of local workers generated construction errors due to the worker's lack of experience, knowledge and competence. As the project progressed and construction errors became increasingly prevalent, the contractor spent a disproportionate amount of time resolving problems that arose. For these small and geographically distributed sites, staff supervision is quintessentially important in controlling the quality of construction works via front-line managers and the workforce.

Previous research undertaken by Love (2002) for example revealed that there were no significant differences between procurement methods and rework costs. However, the case study analyzed in this paper reveals that the characteristics of the procurement path were a contributor to rework. In these cases, a proportion of rework costs were attributable to execution errors and management problems by the contractor, while costs due to scope modifications were naturally incurred by the client. However, under PBP rework costs due to scope modifications had to be allocated in the awarded budget provoking budget exchanges between projects so as not to overtake the awarded budget.

The special characteristics of the urban renewal projects (such as rehabilitating deteriorated infrastructures) can require significant investment. To improve the performance of these projects, strategies for life-cycle risk mitigation are needed (Hastak and Baim, 2001). The risk associated within an event is a combination of the probability of that event occurring in the time frame under consideration and severity of 
its occurrence. Where more complex events are involved, the risk is traditionally defined as the summation of associated individual events, weighted according to the degree of importance of each individual event (Rescher 1983). In the context of the research presented the identification of rework causation is understood by considering the whole project system holistically and how variables dynamically interact (Love and Edwards 2004; Aljassmi and Han, 2013; Li and Taylor, 2014).

Further research is required to identify the probability of occurrence between the identified causal factors and rework levels (Love and Edwards 2004). Once the probability of occurrence between the identified causal factors and rework levels can be determined, this model will provide the public sector with an objective assessment of the likelihood of rework levels given prevailing conditions. However, the procurement processes to which Colombian urban renewal projects are subject exposes to corruption (Signor et al 2016). Procurement is one of the biggest areas of internal weakness to corruption risk. Public contracts in Colombia are awarded based on the lowest price. Lowest price bidding is more likely to result in time and cost overruns due to opportunistic behavior of contractors, which can lead to poor value for money and significantly higher whole life costs (Love et al 2012).

Lump sum contracting stimulates contractors to bid for work at unrealistically low levels. It then becomes difficult for them to maintain standards and obtain optimum profits, the quality of their work falls and they become more likely to make claims (which may be unjustified in many instances), delay payments to subcontractors and indulge in corrupt behavior to reduce their losses. To mitigate corruption risks reforms to the public procurement processes should be implemented while contractors could help by maintaining high ethical standards in their own operations.

\section{DISCUSSION}

While limited systematic knowledge is available on construction rework dynamics, generic models of rework have been developed for building civil engineering projects (Love et al., 2011, Forcada et al., 2014), residential apartments (Love et al., 1999 and Love et al., 2008) and for complex hydrocarbon (oil and gas) projects (Love et al., 2011). These aforementioned studies revealed that rework experienced was predominantly generated from the project's conception and design stages - poor quality documentation and design errors led to changes being implemented during construction. These previous findings resonate with those obtained from this research, particularly, a lack of design and errors in allocating the budget were predominant factors leading to rework. However, the causes of these design errors were very different from those obtained in other previous research. Special characteristics of public contracts in Colombia were determinant on the occurrence of rework. The obligation to conduct community socialization meetings to seek permissions before commencing works, or when a change was required, also generated rework.

Although the generic systemic model of rework for other civil engineering projects has already been developed, their complexity and the characteristics of such projects are 
very different from the case study presented in this paper. Specifically, urban renewal projects are unique and more akin to those of restoration (Tran et al 2015). For larger complex projects, the management team's skill levels enable efficient and effective coordination and integration of project participants as a means of reducing rework (Love et al., 1999 and Love et al., 2008; Love et al., 2011; Forcada et al., 2014). Regarding coordination aspects, the contractor's ability to manage financial matters and solvency when allocating material, equipment and workmanship resources were also a cause of rework. In contrast to highway infrastructures assets, the reduced area and scope of each project reduced the need to deal with surrounding aspects such as traffic during the construction process.

Undertaking design reviews and verifications is the first step to minimizing the potential impact of errors, but these practices will not prevent them from occurring. With this in mind, consideration needs to be given to employing an adviser for the community representative who has sufficient construction skills and knowledge to define specifications and to changing the procurement path such that greater shared responsibility is placed on all contractual parties (Love and Edwards 2004, Palaneeswaran et al 2014).

If job creation is the reason of contracting unskilled personnel, training must be provided in order to improve work practices. If municipalities do not begin to reexamine their contract clauses and procedures, then there is a danger that errors become a norm and adversely impact on their overall profitability and the performance of the projects that they are involved with. Selection of contractors based on experience and solvency and making sure that resources are available to undertake the required work are other suggestions to minimize errors and thus reduce rework. Municipalities should pay increasing attention to effectively managing their human resources and implementing quality management practices.

The constant urban transformation of Colombian cities due to the MDP, the infrastructural demands of this country and this study's findings suggest that other public projects that are currently underway should be scrutinised. The methodology adopted for the analysis presented in this paper might be used to analyse the factors that contribute to rework in public building projects and then enhance understanding about the dynamics of rework and develop improvement strategies. The findings of this research are directly applicable to other South American countries such as Brazil, Mexico and Chile were the urban development projects are also awarded under the PBP.

\section{CONCLUSIONS}

In Colombia, the dynamics of rework in urban improvement projects is largely unknown, this despite the fact that construction works are often neither properly defined nor executed. Consequently, project performance is reduced significantly by unnecessary instances of rework. In this paper, the factors contributing to rework on 69 urban improvement projects in the city of Medellin, Colombia, were identified and used to produce a generic systemic model that illustrates the relationships between variables. An analysis of rework costs, initial awarded budget and modified budget provided clarity on the causes of scope and budget modifications encountered. The research 
findings differ greatly from those civil engineering and construction rework analysis and therefore, confirm that the rework phenomena is particular to the type of project, type of contract, magnitude and location of projects. The Participatory Budget Program (PBP), which is focused on citizen participation, is the main difference between this case study and others within the extant literature. Budget relocation and delays in activities were common in all projects. However, thanks to parallel activities the project did not exceed on time neither on cost.

On average, the awarded budget was inflated. A comparison between the 'awarded' and 'corrected' budget, revealed that the awarded budget was $16.4 \%$ above the real corrected budget. This situation occurred because of: i) a detailed analysis of planned construction works was not conducted during the design process; and ii) a shortage of technical visits during the design process was apparent. Various problems encountered included: technical measurements for many of the projects were incorrect; non-viable works or not required activities; necessary works were sometimes omitted from the designs or budgets. Therefore, many budget modifications and budget exchanges between projects from the same district were carried out to balance costs and spend the entire awarded budget. The corrected budget was calculated to obtain the real deviation based on real quantities to be executed. Scope errors and poor design documentation, generated additional changes and rework which inflated the final executed budget to be $21.1 \%$ of the corrected budget. The most important factors contributing to rework were the: wrong initial budget derived from an inaccurate design; constant modifications and scope changes provoked by the lack of clarity about the works; and slow client resolution on queries. Although rework costs due to the client's scope modifications, accounted for $51.3 \%$ of the project's total cost, this cost increase was incurred by other project modifications and by changing specifications. Rework costs due to unexpected events, accounted for $4.6 \%$ of the project's total cost but incurred by the contractor. These costs were mainly due worker inexperience, pressure to finish works, stress and inadequate budget management when allocating material and equipment resources.

The contribution of the city's inhabitants is fundamental to defining urban improvement actions. However, the PBP does not include advising the community on technical aspects when defining their needs and thus produces technically unviable solutions. Municipalities should guide initiatives and help districts address their needs, whilst communities should understand that these initiatives aim to improve the city in a homogenous whole. Understanding how variables that contribute to rework inter-react with one another provides a new insight that could lead to behavioural adjustment. This may be achieved by formally recognizing rework as a key performance indicator within urban improvement contracts and linking it to a risk/reward model of compensation. It is suggested that this would stimulate learning and process improvements for future similar projects. Future research should focus on developing probabilities and better define the potential impact of risks that arise from the contract documentation process. The use of probabilistic network models, such Bayesian networks could present a suitable tool for measuring and managing rework in projects due to their ability to take into causal relations. 


\section{REFERENCES}

Alcaldia de Medellin. (2010). "ABC Planeación Local y Presupuesto participativo." Medellin.

Alcaldia de Medellin. (2012). "Plan de Desarrollo · 2012 - 2015 Medellín, un hogar para la vida." Medellin.

Alcaldia de Medellin. (2001). "Plan de Desarrollo 2001-2003 Una Antioquia Nueva." Medellin.

Alcaldia de Medellin. (2004). "Plan de Desarrollo 2004-2007 Una Antioquia Nueva un hogar para la vida." Medellin.

Alcaldia de Cali. (2003). "Manual de diseño y construcción de los componentes del espacio público." Cali.

Aljassmi, H. and Han, S. (2013). "Analysis of causes of construction defects using fault trees and risk importance measures." Journal of Construction Engineering and Management, 10.1061/(ASCE)CO.1943-7862.0000653, 870-880.

Alessandri, T., Ford, D., Lander, D., Leggio, K. and Taylor, M. (2004). "Managing risk and uncertainty in complex capital projects." The Quarterly review of economics and finance, 44(5): 751-767.

Barber, P., Sheath, D., Tomkins, C. and Graves, A. (2000). "The cost of quality failures in major civil engineering projects." International Journal of Quality and Reliability Management, 17(4/5): 479-492.

Burati, J.L., Farrington, J.J. and Ledbetter, W.B. (1992). "Causes of quality deviations in design and construction." Journal of Construction Engineering and Management, 118(1): 34-49.

Cooper, K.G. (1980). "Naval shipyard production: a claim settled and a framework built." Interfaces, 10(6):30-36.

Dissanayake, G.M., Fayek, A.R., Campero, O. and Wolf, H. (2003). "Measuring and classifying construction field rework: a pilot study." Proceedings CSCE Annual Conference, 5th Construction Specialty Conference, Moncton, N.B., June 4-7, published on CD-ROM, 1-7.

Fayek, A.R. (2004). "Developing a standard methodology for measuring and classifying construction field rework." Canadian journal of civil engineering, 31(6): 10771089.

Flyvbjerg, B. (2006). "Five misunderstandings about case-study research." Qualitative Inquiry, 12(2):219-245.

Forcada, N., Rusiñol, G., Macarulla, M. and Love, P.E.D. (2014). "Rework in highway projects." Journal of Civil Engineering and Management, 20(4): 445-465.

Hastak M., and Baim.J. (2001) "Risk Factors Affecting Management and Maintenance Cost of Urban Infrastructure." Journal of Infrastructure Systems, 7(2): 67-76.

Hwang, B., Thomas, S.R., Haas, C.T. and Caldas, C.H. (2009). "Measuring the Impact of Rework on Construction Cost Performance." Journal of Construction Engineering and Management, 10.1061/(ASCE)0733-9364, 135:3(187), 187-198.

ICEX, España Exportación e Inversiones (2012). "Situación actual del sector de la infraestructura en Colombia." Oficina Económica y Comercial de la Embajada de España en Bogotá.

Koskela, L. and Huovila, P. (1997). "On Foundations of Concurrent Engineering.” Proc. Concurrent Engineering in Construction CEC'97. 
Kvale, S. (1996). Interviews: An Introduction to Qualitative Research Interviewing, Sage, Thousand Oaks, USA.

Li, Y. and Taylor, T. (2014). "Modeling the impact of design rework on transportation infrastructure construction project performance." Journal of Construction Engineering and Management, 0.1061/(ASCE)CO.1943-7862.0000878, 04014044.

Love P. E. D. and Li H. (2000). "Quantifying the causes and costs of rework in construction." Construction Management and Economics, 18(4) 479-490.

Love, P.E.D., Mandal, P. \& Li, H. (1999). "Determining the causal structure of rework influences in construction." Construction Management and Economics, 17(4): 505517.

Love, P.E.D. (2002). "Influence of Project Type and Procurement Method on Rework Costs in Building Construction Projects." Journal of Construction Engineering and Management, 128(1):18-29.

Love, P.E.D. and Edwards, D.J. (2004). "Forensic project management: The underlying causes of rework in construction projects." Civil Engineering and Environmental Systems, 21(3):207-228.

Love, P.E.D., Edwards, D.J., and Irani, Z. (2008). "Forensic project management: An exploratory examination of the causal behavior of design-induced error." IEEE Transactions in Engineering Management, 55(2):234-248.

Love, P.E.D., Edwards, D., Watson, H. and Davis, P. (2010). "Rework in Civil Infrastructure Projects: Determination of Cost Predictors." Journal of Construction Engineering and Management, 10.1061/(ASCE)CO.1943-7862.0000136, 275-282.

Love, P.E.D., Edwards, D.J., Irani, Z. and Goh, Y.M. (2011). "Dynamics of rework in complex offshore hydrocarbon projects." Journal of Construction Engineering and Management, 0.1061/(ASCE)CO.1943-7862.0000377, 1060-1070.

Love, P.E.D., Edwards, D.J. and Irani, Z. (2012). "Moving beyond optimism bias and strategic misrepresentation: An explanation for social infrastructure project cost overruns." IEEE Transactions on Engineering Management, 59(3):560-571.

Love, P., Wang, X., Sing, C., and Tiong, R. (2013). ”Determining the Probability of Project Cost Overruns." Journal of Construction Engineering and Management, 10.1061/(ASCE)CO.1943-7862.0000575, 321-330.

Lyneis, J.M., Cooper, K.G. and Els, S. (2001). "Strategic management of complex projects: a case study using system dynamics." System Dynamics Review, 17(3):237-260.

Morse, J. and Richards, L. (2002). Readme first for a user's guide to qualitative methods. London, Sage Publications.

OECD (2015). "Estudios económicos de la OECD Colombia, Enero 2015, Visión General".

Palaneeswaran, E., Love, P.E.D., Kumaraswamy, M.M. and Ng, T.S.T. (2008). "Mapping rework causes and effects using artificial neural networks." Building research and information, 36(5):450-465.

Palaneeswaran, E., Love, P., and Kim, J. (2014). "Role of Design Audits in Reducing Errors and Rework: Lessons from Hong Kong." Journal of Performance of Constructed Facilities, 10.1061/(ASCE)CF.1943-5509.0000450, 511-517.

Presidente de la República de Colombia, (1998). "Decree 1504 for the development and maintenance of public space." Colombia.

Rescher, N. (1983). Risk: A philosophical introduction to the theory of risk evaluation and management, University Press of America, Washington, D.C. 
Rogge, D.F., Cogliser, C., Alaman, H. and McCormack, S. (2001). "An investigation of field rework in industrial Construction." Construction Industry Institute, University of Texas at Austin, Austin, Tex.

Signor, R., Love, P., and Olatunji, O. (2016). "Determining Overpricing in Brazilian Infrastructure Projects: A Forensic Approach." Journal of Cosntruction Engineering and Management, 10.1061/(ASCE)CO.1943-7862.0001156, 06016001.

Tran, D., Hallowell, M., and Molenaar, K. (2015). "Construction Management Challenges and Best Practices for Rural Transit Projects." Journal of Management in Engineering, 10.1061/(ASCE)ME.1943-5479.0000297, 04014072.

Williamson, O. (1979). "Transaction cost economics: The governance of contractual relations." The Journal of Law and Economics 22(2):233-261.

Yin, Robert K., (1984). Case Study Research: Design and Methods, Sage Publications, Newbury Park.

Zhang, D., Haas, C., Goodrum, P., Caldas, C. and Granger, R. (2012). "Construction Small Projects Rework Reduction for Capital Facilities.” Journal of Construction Engineering and Management, 10.1061/(ASCE)CO.1943-7862.0000552, 13771385. 